\title{
Challenges For Higher-Order Thinking Skill (HOTS) Implementation: Reports From EFL Classroom Teachers
}

Ima Kusumastuti, Endang Fauziati, Sri Marmanto

Master Degree of English Education Department Universitas Sebelas Maret, Surakarta, Indonesia

Email corresponding author: koesimaahmad@gmail.com

How to cite this paper: Kusumastuti, I., Fauziati, E., \& Marmanto, S. (2019). Challenged for Higher-Order Thinking Skill Implementation: Reports From EFL Classroom Teachers. International Journal of Language Teaching and Education, 3(2), 108117. https://doi.org/10.22437/ijolte.v3i2.7579

Accepted: October 15, 2019

Published: December 31, 2019

Copyright @ 2019 International Journal of Language Teaching and Education

This work is licensed under the Creative Commons Attribution International License (CC BY 4.0). http://creativecommons.org/licenses /by/4.0/

(c) (i)

\section{Abstract}

Higher-Order Thinking Skills (HOTS) become the current educational issues in Indonesia. The teachers have to be aware of its importance and have sufficient knowledge about it. This study aims to investigate junior high school teachers' perceptions and challenges in employing HOTS in the EFL classroom. This case study involved two junior high school English teachers from different schools. Data were collected through interviews and classroom observation for triangulation purposes. The findings showed that teachers have been conscious of the importance of HOTS, but they have different perceptions and different ways of implementing HOTS in their EFL classroom. However, there are also challenges that the teachers have to face when they employ HOTS in their classrooms.

\section{Subject Areas}

EFL Classroom

\section{Keywords}

Case Study, HOTS, EFL classroom, teachers' challenges

\section{Introduction}

The modern education world requires $21^{\text {st }}$-century learning and is aimed for the students to reach $21^{\text {st }}$ century life skills. Beyond the achievement of the necessary competencies, the students are also required to master what so-called with higher-order thinking skills (The Ministry of Education and Culture, 2018). Discussing HOTS, it cannot be separated from the cognitive domain of Bloom Taxonomy, which has been revised by Bloom's students, Anderson and Krathwohl (2001). Those thinking skills of the cognitive domain are divided into six levels includes knowledge, comprehension, application, analysis, evaluation, and creation (Anderson and Krathwohl, 2001). The first two levels; knowledge and comprehension, are known as lower-order thinking skills (LOTS). Application and analysis are categorized into middle-order thinking skills (MODS), and the last two levels are called higher-order thinking skills (HOTS). Brookhart (2010) divided HOTS into three basic concepts: as a transfer of one concept to a new situation; as the 
critical thinking skills; as the ability of problem-solving. However, HOTS is one of the basic skills which are required in $21^{\text {st }}$-century learning, namely critical thinking, creative, collaborative, and communicative (The Ministry of Education and Culture, 2018).

Looking at the importance of HOTS in education, the Indonesian new curriculum is designed to fill the need for students' thinking ability, which is called with higher-order thinking skills (HOTS). Starting from 2016, the government includes HOTS in National Evaluation. HOTS is not only a type of assessment item, but it is also employed as a learning method (Istiqomah, 2018). Those learning methods have to cope with the thinking ability, models, application and must deal with students' different abilities. In this case, teachers are required to have sufficient knowledge and understanding of HOTS and its implementation. In the teaching and learning process, teachers should be able to design and implement HOTS combined with the subject matters (Sutarto, 2017).

Higher Order Thinking Skills (HOTS) are principally construed as cognitive activities that are further than the step of recall and comprehension in Bloom's taxonomy (Bloom, 1956 Nagayar, 2015: 5354). Brookhart (2010) proposed that there are three basic concepts of higher-order thinking skills as a transfer of one concept to another concept. It means that the students have to be able to attain knowledge and skills and apply that knowledge and skills to a new situation; as critical thinking skills, is believed to be a cognitive process or a mental activity that allows knowledge to be acquired such as the ability understand the problems logically, reflective thinking skills and the ability to argue that focused on making a decision or doing something; as the ability of problem-solving or the ability of finding a new way, remarkable solution and defining the problems creatively. It emerges that HOTS can be defined as a high level of cognitive activity which includes the ability to transfer more concepts in a new situation, defining the problem logically and solving the problem creatively, arguing critically and making a conclusion (Brookhart, 2010).

Anderson and Krathwohl (2002, p. 215) proposed the three domains which are categorized into Higher Order Thinking Skills as follows (1) Analyzing is the act of breaking the material into its constituent parts and $i$ how the parts relate to one another and an overall structure or purpose. The activities include differentiating, organizing and attributing; (2) Evaluating is defined as making judgments based on criteria and standards through checking or critiquing; (3) Creating refers to putting elements together to form a novel, coherent whole or make an original product. It includes generating, planning, or producing. Higher-order thinking skills require a higher thinking process than just restating the accessed facts. The students are required to understand, make a conclusion, linkage the information (facts and conception) acquired with the other information, categorize, manipulate, connect them creatively, and apply them as the problem-solving (Thomas \& Thorne, 2009). HOTS is thinking skills that require not only the ability to remember, but also other higher abilities, including the ability to analyze, evaluate, and create.

Teaching English is commonly conducted by different teachers who bring various experiences and knowledge into the classroom. What the teacher brings into the teaching-learning process will influence 
the students' outcomes. By exploring their perceptions, the result will become one of many references that may evaluate their behaviors towards the classroom (Borg, 1999). By evaluating what the teachers do in the classroom, it may result in improving students' achievement, especially in the EFL classroom.

There are some studies observing teachers' perspectives toward HOTS and its implementation. Fakhomah and Utami (2018) conducted their study about pre-service English teachers' perceptions and difficulties in employing HOTS in $21^{\text {st }}$-century learning. In this study, 5 pre-service teachers of Professional Teachers Program from different Universities were involved in this research. The result found that those five teachers have high perceptions of HOTS in their classrooms, but they faced some difficulties in its implementation, such as time management and students' abilities.

Another study is from Mursyid and Kurniawati (2019), who studied the perceptions of HOTS among teachers across generations in the EFL classroom. This study was aimed at investigating teachers' perceptions, the practices, and the constraints in conducting HOTS in teaching the foreign language. The result reported that the teachers from all generations are aware of HOTS, and they apply it in their teaching in a different way.

In recent years, the Indonesian stakeholders in education are trying hard to develop students' higher-order thinking skills in order to permit them to be creative and critical thinkers (Istiqomah, 2018). However, developing HOTS, for junior high school students, mainly in the EFL classroom, is not easy and challenging for them. Teachers face many difficulties in delivering English subject materials that employ HOTS in it. Students' different characteristics, level of intelligence, and motivation become the factors which may influence their teaching-learning process (Juhansar et al., 2018). Besides, in their research, Yen, and Halili (2015) stated that it is challenging to implement HOTS in the classroom for several reasons, such as time-consuming, students' motivation, teachers' competences and professionalism, classroom management and also resources. This implied that teaching language with HOTS is considered to be challenging for the teachers as many factors influence the teachers' efforts in conducting HOTS especially in language teaching.

However, HOTS training held by the government for teachers is still limited. Almost of teachers get the knowledge and information about HOTS by themselves. They learn about HOTS from many books or other references such as the internet. As they are required to develop HOTS in their classroom even with limited knowledge, teachers face many challenges in teaching the students to achieve higherorder thinking skills.

By revealing teachers' perceptions regarding HOTS implementation and its challenges, it can help the educational policy-makers and the teachers in revisiting, re-evaluating, and developing the foreign language education system especially those related to HOTS.

\section{Method}


This study investigated junior high school teachers' perceptions toward the implementation of HOTS, especially in the EFL classroom. For this purpose, the following research questions were designed:

1. What are junior high school teachers' perceptions about the implementation of higher-order thinking skills in the EFL classroom?

2. What challenges do junior high school teachers face in implementing HOTS in the EFL classroom?

Two English junior high school teachers participated in this study. Their teaching experiences ranged from 6 months to 15 years. The first teacher (T1) is a female teacher who teaches English in a public junior high school. She has taught English for 16 years and has been certified as a professional teacher. She is graduated from a Master's Degree in English education program. She has once joined HOTS training of English Teachers Community in her area. The last teacher (T2) is a male teacher who teaches in a private junior high school. He has taught English for six months and has not been certified as a professional teacher. He has never joined any HOTS training.

This study conducted using qualitative research in the type of case study. Creswell (2009) states that the case study is a strategy of inquiry in which the researchers explore in-depth a program, event, activity, process, on one or more individuals. Therefore, this study used a case study because the researchers needed to know more in-depth about the particular case regarding teachers' perceptions about the application of HOTS mainly in teaching EFL classrooms and the challenges faced by the teachers.

In exploring teachers' perceptions of HOTS in teaching EFL Classroom, the researchers used openended questions to interview the teachers. The data that were obtained from the interview was in the form of interview transcripts. After interviewing the teachers, the researchers conducted a classroom observation in order to observe what the teachers do in their classroom practices and how they apply their perceptions of HOTS. Their attitudes in implementing HOTS in the classroom and also students' responses in the learning process were compared with interviews and document analysis results. The documents were the secondary data included: the curriculum, lesson plan, and course list, which provided information about the course contents and class schedule of teachers involved in this research.

Three data collection technique was employed to answer the research questions, namely; Interview, Documents Analysis, and Classroom Observation. A semi-structured interview was used in this research. It was about questions investigating teachers' perceptions about HOTS in teaching EFL classrooms, which includes teachers' views about HOTS, its importance, its classroom implementation, and the problems faced by teachers in the EFL classroom. The documents used were the curriculum, lesson plan, and course list, which provided information about the course content and class schedule of the two teachers. Multiple methods and multiple sources of data triangulation were used to check the trustworthiness of data. This research used triangulation in the type of multiple sources of data by using participants, events (field notes), and documents to confirm the emerging findings. The researchers also used several methods or techniques such as interviews, documents, and observation, to collect the data, and to make it more valid. 


\section{Result and Discussion}

\subsection{Teachers' perceptions about the implementation of HOTS in the EFL classroom}

Generally, the participants did not reject the use of HOTS in Indonesian recent curriculum K13. Both of them are aware of the importance of HOTS used in teaching English. The participants said that HOTS is essential and as it is included in the government's education program such as in curriculum and assessment, teachers have to be able to understand and master it.

"I think HOTS is important for the student. HOTS... As I have read before, it was implemented in the students' assessments. However, in my opinion, HOTS should also be included in the teaching-learning process. Therefore, teachers have to be able to stimulate the students to be responsive not only based on the textbooks but from their own experiences. By doing this kind of activity, the students will be able to relate their knowledge and experiences and think critically." (T1, 29 May 2019.

Another participant had a similar view as $\mathrm{T} 1$ as follow:

"HOTS is the government's program in education. Well, I think it is an outstanding program that the government is trying to improve the students' qualities in education. For that reason, we have to understand how to teach our students not only about the questions in the textbook. We have to be able to teach them with HOTS, and I am sure that it will help us in classifying which students are good and which is not." (T2, 9 April 2019)

"... HOTS is very good for our education system, and it is crucial. I knew HOTS from internet sources." (T2, 9 April 2019)

Besides, the teachers also gave their view about the implementation of HOTS in EFL classrooms. Generally, teachers thought that they had applied HOTS in their classroom, but almost of them did not know how it should be.

"I tried to follow textbooks' instructions to apply HOTS in my class. I... or maybe the other teachers are still exploring how we can employ HOTS in our classroom." (T2, 9 April 2019)

Teacher 1 (T1) gave the same opinion about the implementation of HOTS in her school. She stated that the implementation of HOTS depends on the efforts of the teacher itself because the references and the training of HOTS are still limited for the junior high school level.

"I had found HOTS references many times, but again and again it was devoted to the senior high school level. I had never found any reference for the junior high school level. However, there was an instruction that a part of the students' assessment would be in the type of HOTS. (T1, 29 May 2019)

To sum up, teachers have positive perceptions of HOTS implementation in their EFL classroom even though they have limited knowledge and references for it. They also feel the importance and need for 
HOTS to be conducted in the teaching-learning process because they consider that HOTS can increase students' quality of education.

Teachers' challenges in implementing HOTS in EFL classroom

Each participant faced different difficulties in implementing HOTS. Teacher 1 (T1) stated that teachers' knowledge and understanding of HOTS would influence them in its implementation.

"I think HOTS is important for the student. HOTS... As I have read before, it was implemented in the students' assessments. However, in my opinion, HOTS should also be included in the teaching-learning process. Therefore, teachers have to be able to stimulate the students to be responsive not only based on the textbooks but from their own experiences. By doing this kind of activity, the students will be able to relate their knowledge and experiences and think critically." (T1, 29 May 2019)

"I had never heard about HOTS when I was still at the University. I started to know about HOTS when we are told that a part of the assessment would contain HOTS, and we had to include HOTS in our teaching. Then, I used the internet as the source of my reference for HOTS." (T2, 9 April 2019)

Besides, the references about HOTS, mainly for junior high school level, are still limited. However, teachers are required to employ HOTS in the learning process because the assessment will contain HOTS. "I had never found any reference for the junior high school level. However, there was an instruction that a part of the students' assessment would be in the type of HOTS.” (T1, 29 May 2019)

"I hope that there will be HOTS training for the teachers by the government. At least, the governments create a web page where the teachers may learn about HOTS from it." (T2, 9 April 2019)

Students' different characteristics and abilities also influenced their attitudes toward HOTS in the English classroom.

“... not all the students can cope with HOTS. It depends on their intelligence. It is easy to teach with HOTS in the class with high intelligence students. They are curious. They feel comfortable with it. However, when we have to deal with the other students, of course, we should be patient. We need more time to make them deal with HOTS in English class. On the other hand, we have to reach our target. Besides, students' characteristics will also influence their learning style." (T1, 29 May 2019)

"I do agree with the HOTS program, but there should be a bridge to facilitate slow learners in dealing with HOTS. It got positive feedback from the fast learners. For slow learners, they faced many difficulties with HOTS.” (T2, 9 April 2019) 
In general, teachers had tried some efforts in conducting HOTS in their English classrooms. There were many difficulties faced by junior high school teachers in implementing HOTS that emerged from the data. Those difficulties were teachers' competences, students' abilities and motivation, resources, and time-consuming.

\subsection{Discussion}

For recent years, higher-order thinking skills (HOTS) are significant in Indonesia (Istiqomah, 2018). The needs for 21st-century life skills mastery required the students, teachers, and education stakeholders to deal with $21^{\text {st }}$-century learning, which includes critical thinking, creative, communicative, and collaborative (The Ministry of education and Culture, 2018). Almost all of those characteristics can be achieved with HOTS. Therefore, started in 2016, the Indonesian government includes HOTS in the National curriculum. For junior high school level, the term HOTS was firstly started in National Examination Blueprint and implemented for about 15\% of National Examination items (National Examination Blueprint, 2016). As HOTS cannot be implemented only in assessment, teachers, as the planner, facilitator, and also the person responsible for the teaching-learning process are required to have sufficient knowledge and understanding about it. In their study about pre-service English teacher perception about HOTS, Fakhomah and Utami (2019) found that the participants agreed with the implementation of HOTS because it can improve students' critical thinking, readiness toward globalization, and make them more active. Similarly, the result of the study showed that the participants had high perceptions of HOTS in teaching English. They were aware of the importance of developing HOTS in their classrooms. In their opinion, by developing HOTS in the teaching-learning process, the students are highly motivated to have the characteristic of critical thinking, problem-solving, and also applying what they have learned in real life.

Dealing with the new curriculum, namely K13, teachers were trying hard to develop HOTS in their EFL classroom. Based on the interview result, the teachers conducted their teaching-learning process based on the textbook and dealt it with the students' condition and classroom situations. The teachers said that there was never any training which focused on HOTS held by the government in their area. They should actively find the information connected with HOTS by themselves, whether it was from books or internet references in order to meet with the students' needs in $21^{\text {st }}$-century learning. This is in line with Seman et al. (2017) who find that teachers' limited knowledge of HOTS made them follow textbook instructions which contained HOTS in it. A statement from T1 who found that some teachers in her school took an effort to know in-depth about HOTS and employed it in their classroom as well, but some others were only wanted to know it. Some teachers still focused on the level of knowledge, which was defined as lower-order thinking skills (LOTS). They did not develop HOTS in their classrooms and conventionally taught their students. It means that the implementation of HOTS in the classroom practice depends on teachers' efforts and creativity. Mostly, the teachers were highly aware of the importance of higher-order thinking skills (HOTS) employed in junior high school English classroom, but they had a different way in its practice. Besides, several factors made it difficult to develop it. This is in line with the study of Seman et al. (2017) who revealed that teachers found several challenges in teaching 
and learning for HOTS

The other result showed that each participant faced their challenges in developing HOTS in their English class. Teachers were still confused about defining HOTS. Moreover, they had limited knowledge in employed HOTS in the learning process and even the assessment. For instance, T1 stated that every teacher had their level of knowledge and understanding about HOTS as there was no HOTS training held by education stakeholders in their area. Their knowledge and understanding improved depend on their efforts in getting information and learning about HOTS. This is affordable with Seman et al. (2017) who states that the majority of teachers only had a very basic knowledge of HOTS and they had misconceptions about some key components of HOTS. T2 hoped that the government, through English Teachers Community in his area, would make a kind of training that focused on HOTS to help English teachers having the same perceptions about what HOTS is, its significance, classroom practice, and assessment. Thus, both of the teachers agreed that their lack of knowledge toward HOTS brought them difficulties in teaching and assessing their students. For that reason, improving English teachers' professional and pedagogical knowledge of HOTS would help teachers in developing it in their classroom and facilitating the students to achieve HOTS in English class. This finding related to the study which comes from Seman et al. (2017) who finds that teachers should know various learning theories to design teaching methods that are suitable for students with different learning styles so that they could stay focused during teaching and learning sessions.

Limited resources in teaching English with HOTS also made the teachers challenging to plan the lesson as T1 said that the references about HOTS in the level of junior high school was still limited and it was tough to find appropriate textbook which dealt with the implementation of HOTS in that level. Frequently, the teacher should use many different textbooks and combined suitable activities to meet the appropriate materials for the students, and it was time-consuming. The pre-planned lesson, at times, did not match with the on-going classroom, and teachers should switch to another strategy which appropriates with it. T2 affirmed that he had never learned about HOTS when he was in university. The Internet was the only resource of information where he might learn from, and it was difficult to practice what he had learned into his classroom. It was clear that adequate resources would help teachers to have sufficient knowledge and find the most appropriate method in developing HOTS in the classroom. This finding related to Seman et al. (2017) who believe that teachers need to be given extensive training about HOTS.

Moreover, teachers were required to finish his materials on the one hand. On the other hand, the HOTS teaching-learning process needed much time to conduct in the classroom. Every student was different in ability, characters, and motivation. In employing HOTS, teachers should understand the students personally. It took teachers' extra time and hard work to create an effective teaching-learning process for those students. HOTS concepts, such as critical thinking and problem-solving, could not be learned in a short time. It needed a long time to assist the students in being more critical, active, and creative. Besides, students' self-motivation also played an essential role in encouraging them to be more active in the classroom. Vocabulary mastery became the main challenge for English teachers in the EFL classroom. Mostly, students were challenging to understand the materials being learned. As English as a 
foreign language for them, they were also faced difficulties in expressing their idea orally in English. Thus, the students preferred not to be actively involved in classroom activities. Their lack of vocabulary mastery leads them to have less motivation in joining the classroom with HOTS atmosphere. Therefore, teachers were required to find the appropriate strategies which might facilitate the students to achieve HOTS as their learning outcomes. This is different with Seman et al. (2017) who found that the teachers faced the challenges of the students who had different learning abilities and learning styles.

\section{Conclusion}

Teaching with HOTS is necessary for education because it leads the students to have the critical thinking, the ability to adjust what they have learned into real life, and the ability to solve the problem creatively. Generally, teachers were aware of the importance and had high perceptions of HOTS. Their limited knowledge about HOTS did not prevent them from developing HOTS in their classrooms. They tried hard to find an appropriate strategy to employ HOTS which suitable for their students and school condition. Limited resources of HOTS, mainly for junior high school level, become their challenges in teaching with HOTS. Those teachers hoped that there would be a specialized HOTS training for the English teachers in developing HOTS both in the teaching-learning process and assessment.

As English is a foreign language in Indonesia, teachers were challenging to involve HOTS in their English classes. Students' lack of vocabulary mastery became the main barrier in conducting HOTS. Students were required to be actively involved in HOTS classrooms. However, their difficulties in understanding the materials they learned lead them to be passive during the learning process. Their less motivation, then, prevent them from expressing their critical thinking and creativity. However, achieving HOTS will enable the students to have $21^{\text {st }}$-century life skills which are essential for them in facing world globalization. Therefore, teachers' knowledge and understanding of HOTS have to be increased as they play important roles in assisting the students to achieve higher-order thinking skills.

This study was conducted to reveal teachers' perceptions about HOTS, mainly in junior high school level and find the difficulties faced by the English teachers in developing HOTS in classroom practices. The current study is intended to help teachers, curriculum developers, and also decision-makers to have more information about HOTS implication in the education system. This study can be seen as a reference for the teachers to evaluate their teaching beliefs and practices.

\section{References}

[1] Anderson \& Krathwohl, D. R. (2001). A revision of Bloom's taxonomy: An overview. Theory into Practice, 41-4, 212-218.

[2] Borg, S. (1999). Studying teacher cognition in second language grammar teaching. System 27 pp. 19 $-31$

[3] Brookhart, Susan. M. (2010). How to assess Higher-Order Thinking Skills in your classroom. ASCD 
Publications.

[4] Creswell, J.W. (2009). Research design: qualitative, quantitative, and mix methods approach. SAGE Publication Inc.

[5] Fakhomah, D.N., and Utami, N.S. (2019). Pre-service English teacher perception about Higher Order Thinking Skills (HOTS) in $21^{\text {st }}$-century learning. International Journal of Indonesian Education and Teaching, e-ISSN 2548-8430, p-ISSN 2548-8422, Vol. 3, No. 1

[6] Istiqomah. (2018). Pembelajaran dan penilaian Higher Order Thinking Skills. Pustaka Media Guru. Surabaya.

[7] Juhansar, J. et al. (2018). The implementation of Higher Order Thinking Skills at Universitas Teknologi Yogyakarta in Indonesia: Opportunities and challenges. Proceedings of the International Conference on Education and Higher Order Thinking Skills (ICE - HOTS).

[8] Kementrian Pendidikan dan Kebudayaan. (2018). Materi penyegaran instruktur Kurikulum 2013 Sekolah Menengah Pertama. Jakarta.

[9] Limbach, B., \& Waugh, W. (2010). Developing higher-level thinking. Journal of Instructional Pedagogy, Vol. 3.

[10]Mursyid, M., \& Kurniawati, N. (2019). Higher-order thinking skills among English teachers across generation in EFL classroom. English Review: Journal of English Education, 7(2), 119-124. doi: 10.25134/erjee.v7i2.1775.

[11]Nagayar et al. (2015). Young Adult Literature and Higher-order Thinking Skills: A Confluence of Young Minds. International Journal of Language Education and Applied Linguistics (IJLEAL) 2015, Vol. 3, 51-61 52

[12]Seman et al. (2017). Teachers' challenges in teaching and learning for Higher Order thinking Skills (HOTS) in primary school. International Journal of Asian Social Science Vol.7, No. 7, 534-545

[13]Sutarto, H. P. (2017). Articulation of high order thinking skills in competency-based instruction in Indonesia Vocational and Technical high school. Advances in Social Sciences, Education, and Humanities Research, 102, 211-217.

[14]Thomas, A., and Thorne, G. (2009).How to increase higher-order thinking, Metarie, LA: Center for Development And Learning, http:www.readingrockets.org/article/34655

[15]Yen, T. S. \& Halili S.T. (2015). Effective teaching of Higher-Order Thinking (HOT) in education. The Journal online of Distance Education and e-Learning, Vol 3, Issue 2. 